\title{
Cultural heritage in Hong Kong, the rise of activism and the contradictions of identity
}

Sebastian Veg

\section{(2) OpenEdition}

\section{Journals}

Édition électronique

URL : http://journals.openedition.org/chinaperspectives/1663

DOI : 10.4000/chinaperspectives. 1663

ISSN : 1996-4617

Éditeur

Centre d'étude français sur la Chine contemporaine

\section{Édition imprimée}

Date de publication : 15 avril 2007

ISSN : 2070-3449

Référence électronique

Sebastian Veg, "Cultural heritage in Hong Kong, the rise of activism and the contradictions of identity », China Perspectives [En ligne], 2007/2 | 2007, mis en ligne le 08 avril 2008, consulté le 28 octobre 2019. URL : http://journals.openedition.org/chinaperspectives/1663 ; DOI : 10.4000/ chinaperspectives. 1663 
U

\title{
Cultural Heritage
}

\section{in Hong Kong}

\author{
The Rise of Activism and the Contradictions of Identity
}

SEBASTIAN VEG

ก he closing of the Star Ferry Pier on 11 November 2006 and its subsequent dismantling in December, to make room for a highway (known as "P2") and a green belt on reclaimed land between Hong Kong station and the Hong Kong Convention and Exhibition Centre, threw unforeseen shock waves among Hong Kong citizens. The 49-year old construction (just short of the 50 years the government advanced as a criterion for "significant" heritage) was not widely seen as architecturally spectacular, but its removal, together with that of the historic clock tower, drew thousands of people for a last visit, and ended in a dramatic (though small) sit-in, canvas-slashing by activist $\mathrm{Ho}$ Loy, a Legislative Council ( $\mathrm{LegCo}$ ) motion requesting that the dismantling be postponed pending further consultation, and petitions signed by thousands of Hong Kong citizens ${ }^{(1)}$. As the Star Ferry Pier appeared beyond saving, after removal of the clock tower and the destruction of the building, attention shifted to the adjacent Queen's Pier, also slated for destruction, perhaps architecturally even more understated, and less related to memories of everyday life, as it was mainly used by visiting dignitaries or the arrival of the governor. Queen's Pier was closed on 26 April 2007, when protesters again staged a sit-in and petition signing. This event received the publicised visit of movie star Chow Yun-Fat. The government responded by proposing to dismantle and reconstruct the pier at a nearby location ${ }^{(2)}$, while the Antiquities Advisory Board voted to grant it Grade I historic building status, stopping just short of recommending monument status, which would ensure protection against its destruction (the final decision rests with the Home Secretary). Just as Donald Tsang had argued in January that too much heritage conservation could harm Hong Kong's competitiveness, Liberal Party chairman James Tien at this point asserted, "Foreign visitors would rather go shopping than see a queen's pavilion, which will not be at the waterfront ${ }^{(3)}$ ".

The rise in cultural heritage demands in fact reveals a new preoccupation with local history and geography. Rather than the ferry terminal itself, it is Victoria Harbour, progressively dwindling due to land reclamation on both sides, which is presumably at the heart of public concern. Commuter-style crossing of the harbour by ferry for a token fare, arguably a defining feature of Hong Kong lifestyle shared by many, will dwindle with the inconvenient new location of the Central Pier (the footbridge leading to it was nowhere near completion when the old Pier was closed), also criticized as "fake old", on the grounds of its design modelled on the original Edwardian Star Ferry Pier rather than its gritty 1950s successor (the Star Ferry began operating in 1888). The present controversy is in fact only part of the ongoing discussion over the past two years of government plans for redevelopment of the Central waterfront (the Central Reclamation Urban Design Study), recently focused on the HK\$5.2 billion construction of a new government complex at the Tamar site in Admiralty ${ }^{(4)}$. Civic Exchange, for one, has questioned the need for such a hugely expanded government building in a prime location, and argued for a "Central Park" in the location instead $^{(5)}$. The underlying assumption in this debate is of course, as more generally in Hong Kong politics, that the government, as well as certain members of LegCo, tend to favour business interests, especially real estate and redevelopment, to which several important "tycoons" are closely linked, over public opinion and democratic consultation.

1. A good chronology of the events is available on the Wikipedia "Edinburgh Place Ferry Pier" entry http://en.wikipedia.org/wiki/Edinburgh_Place_Ferry_Pier, accessed on 20 May 2007. The petition presented by SEE (Society+Environment+Economy), calling for further study and consultation, had been signed by over 8,000 people at the end of May 2007. See: http://www.project-see.net/.

2. See the LegCo motion at http://www.legco.gov.hk/yr06-07/english/panels/plw/papers/ plw0327cb1-1184-4-e.pdf.

3. Ambrose Leung, "Pier failure shows Tsang team 'like a weak crab'", South China Morning Post, 11 May 2007.

4. A public consultation was held on the four proposed designs for two months; they can be viewed at http://www.tamar.gov.hk/; although few technical details (such as the height of buildings) are provided. It appeared during the process that two designs did not meet the open-space requirements and would therefore require further approval if chosen.

5. See "Central Park. City users and public space", http://www.civic-exchange.org/publications/2006/centralpark.pdf, accessed on 27 May 2007. 
(ת)

$\geq \quad$ tral Police Station, Victoria Prison (partly dating back to 1864) or the Pumping Station in Yau Ma Tei ${ }^{(13)}$.

The government, which has hitherto favoured a definition of heritage in line with "central" Chinese culture (the copy of a Tang Dynasty Garden at Diamond Hill) is now confronted with a situation in which this reading of history is contested from all sides: what is seen as characteristic of "Hong Kong culture" is, on the one hand, early colonial architecture and the tenements (or ferry piers) of the 1950s, and on the other a form of tradition that emphasises its difference with Chinese state culture. Traditional, several hundred year-old Hakka villages, preserved in the frontier area closed in 1951, are seen as having strong potential for community-based cultural tourism ${ }^{(14)}$, following the Hakka cultural heritage trail already established in the New Territories. In this respect, it is quite ironic that China is submitting the diaolou buildings of Kaiping (Guangdong province), already on its Tentative List since 2002, to UNESCO for inscription on the World Heritage List in 2007. At the same time, UNESCO's growing interest in "intangible cultural heritage" resonates with local inhabitants' calls to preserve ways of life rather than buildings: the remaining outdoor wet market in Central (an up-scale real estate development is planned in its place by the Urban Renewal authority) the Bauhauss-style Wanchai market and adjacent Wedding Card Street (where residents refused to leave the premises for three years despite compensation), as well as disappearing dai pai dong-style restaurants are certainly expressions of a way of life, if not necessarily "cultural heritage" in the traditional sense ${ }^{(15)}$.

To a degree, some of the issues at stake are the same as in mainland China: lack of government attention to "popular" forms of culture, which are left to real estate developers to carve up as they can. Despite distinctive differences in the legal framework, the question of proximity between government authorities and developers certainly has similar aspects. Nevertheless, Hong Kong's soul-searching on cultural heritage runs somewhat deeper than it can in China. In the perceived contradiction between its status as "Asia's world city" and the local identity which defines an overwhelming majority of its inhabitants, between the luxury urban developments and urban expressions of popular lifestyle such as markets, entertainment, or street restaurants, lies a political question that cannot simply be solved through a consensual definition of "heritage" based on international norms and standards. Criteria for the significance of cultural heritage are complex, with ideas like "exceptional value" or "authenticity" all subject to dispute: while it is of course desirable that the government not hasten their disappearance, supporting privately owned street restaurants, even though they also express traditional culture, is perhaps not the state's role. More generally, it would be paradoxical for a city like Hong Kong to turn away from its cosmopolitan identity and favour a purely local definition of what makes up its cultural heritage. In the final analysis, this question implies political and historical choices as to what is important in defining a community, and the controversy it has raised should be seen as an important aspect of the democratic debate, the outcome of which will no doubt shape the future of Hong Kong. •
13. An exhibition of historic photos and drawings was recently held by the Conservation Association Centre for Heritage (CACHe) in Sai Ying Pun. The old General Post Office, built in 1911 and destroyed in 1976 is one of the most spectacular examples of the destruction of a historically and architecturally significant building.

14. Chloe Lai, "Heritage Zones urged for border villages", South China Morning Post, 25 March 2007.

15. Chloe Lai, "Out with the old", South China Morning Post, 26 March 2007. 